\title{
TEACHERS' IDEAS ON EDUCATION: APPROACHES TO TEACHERS' RESISTANCE TO REFORMS
}

\author{
IDEIAS DOCENTES SOBRE EDUCAÇÃO: \\ ABORDAGENS SOBRE A RESISTENCIA DO \\ PROFESSORADO ÀS REFORMAS \\ LAS IDEAS SOBRE EDUCACIÓN: \\ ENFOQUES SOBRE LA RESISTENCIA DOCENTE \\ A LAS REFORMAS
}

\author{
Elie GHANEM $^{1}$ \\ MARIa SOCORRo TORQuato ${ }^{2}$
}

\begin{abstract}
This text summarizes the arguments guiding a research on the ideas of teachers from São Paulo, Brazil, regarding school education. The research concluded that the teachers' ideas are rooted on a classical, humanist, scientific-based schooling model, and that teachers resist practices that oppose this model. The text presents the grounds for the research's hypothesis: that, whenever there is dissonance between the ideas about education held by those who foster educational reforms and the ideas of teachers, the latter present some form of resistance. Teacher's ideas stem from the socialization of members of this professional category, especially during the period of their basic education. The hypothesis contradicts the common statement of an important portion of the literature on the subject of teacher resistance, according to which that resistance is due to poor teacher training. KeY-words: Teacher attitudes; EduCational theOries; EduCATIONAL REForm.
\end{abstract}

Resumo Este texto sintetiza argumentos elaborados para situar uma pesquisa sobre ideias de docentes paulistas a respeito de educação escolar, tendo concluído que as ideias docentes estão fundadas no modelo de escola clássica humanista de base científica e que resistem às práticas contrárias a esse modelo. Dessa pesquisa, são apresentados aqui apenas os

\footnotetext{
Universidade de São Paulo, São Paulo-SP.

2 Universidade Federal de São Carlos, São Carlos-SP.
} 
fundamentos da hipótese que foi focalizada, ou seja, quando há dissonância entre as ideias acerca da educação das pessoas que promovem reformas educacionais e as ideias docentes, há alguma forma de resistência do último grupo. Tais ideias docentes seriam oriundas da socialização de integrantes dessa categoria profissional, sobretudo do período da sua educação básica. A hipótese contraria a afirmação de parte importante da literatura sobre o tema da resistência, a qual entende que esta se deve à má formação docente.

Palavras-chave: Atitudes de professores; Teorias educacionais; Reforma educacional.

Resumen Este trabajo sintetiza argumentos formulados para situar una investigación sobre ideas de docentes de São Paulo (Brasil) acerca de educación escolar, la cual concluye que las ideas docentes están fundadas en un modelo de escuela clásica humanista de base científica y que el profesorado se resiste a las prácticas contrarias a ese modelo. De esta investigación, se presentan aquí sólo los fundamentos de la hipótesis que se enfocó, o sea, cuando hay disonancia entre las ideas sobre educación de las personas que promueven reformas educativas y las ideas docentes, hay alguna forma de resistencia de este último grupo. Tales ideas docentes serían oriundas de la socialización de integrantes de esa categoría profesional, sobre todo en el período de su educación básica. La hipótesis contrarresta la afirmación de parte importante de la literatura sobre el tema de la resistencia, la cual entiende que ésta se debe a la mala formación docente.

Palabras clave: Actitudes de docentes; Teorías educativas; Reforma educativa.

\section{INTRODUCTION}

This text is an illustration of the hypothesis that there is teacher resistance to educational reforms, among other reasons, due to the discrepancy between the educational ideas contained in the reforms and teachers' ideas about education. It presents the results of a literature review focused on works that consider the reasons for this resistance, and summarizes arguments guiding a research on the ideas of teachers from São Paulo state, in Brazil, regarding school education. Such research concluded that the ideas of teachers are rooted on a classical, humanist, scientific-based schooling model, and that teachers resist practices that oppose this model. The article presents only the basis of the hypothesis addressed in that study. Most of the works reviewed are Brazilian, given that the research's empirical basis lies in the Brazilian context. Works from other countries are considered, since the phenomenon of teacher resistance is not researched as circumscribed to Brazilian reality.

The hypothesis will be illustrated by the discussion of prominent thought lines within the specialized literature on the matter, in which studies verify teacher resistance to the reforms, regardless of their content, perspective, pedagogical consistency, scientific grounds or political justification. These studies also point out the importance of teachers' ideas in adhering or not to educational reforms. Thus, such resistance does not stem from poor teacher training as the literature asserts. Other possible factors that contribute to the contrary attitude of teaching professionals facing reformist measures - such as the absence of this 
professional category in the occasion of the measures' formulation, the imposition of those measures through administrative acts, and the teachers' unsound working conditions - will not be prioritized in the propositions to be examined here.

In order to understand the hypothesis, it is necessary to point out that the concepts of knowledge, thoughts, representations and beliefs of teachers are found within the discussion of the epistemology of teaching practice; and that those concepts sometimes appear entangled; sometimes, as synonyms; and, sometimes, separated. That is why we chose to adopt the concept of idea, which anticipates an action (ABBAGNANO, p. 611), underlining the dispositions of the teachers' acting. However, it is also necessary to emphasize the distinction that some authors, such as Lahire (2004), establish between willingness to act (action habit) and beliefs (mental and discursive habits). For these authors, action does not always correspond to the beliefs of the actors, whether because they do not have the material means to act, or because they have internalized a set of beliefs without having developed habits of action. Therefore, ideas are understood here as those that drive the willingness to act, guide the professional practice of teachers, and indicate how they conceive education and view the processes of teaching and learning, the relationship between teacher and students, and the relationship of the latter to knowledge or to the purposes of formal education.

The hypothesis was raised in order to substantiate a case study aimed at verifying the educational ideas that drive the teachers' practice in two São Paulo public schools, one in the city center and the other in the urban periphery. In this research, we adopt the theoretical reference of Lahire, for whom the actor has a patrimony of dispositions (propensities, behavioral and mental inclinations) resulting from the socialization to which they have been subjected. We also follow Tardif and collaborators, who emphasize the influence of schooling (pre-professional trajectory) in shaping beliefs and practices of teachers at the beginning of their career. Although the literature points to several factors contributing to teacher resistance, we have chosen to specifically analyze teachers' ideas about education, because, according to Etzioni's organizations theory (1974), school is constituted as a normative organization with a cultural goal, that is, the preservation of cultural heritage and its transmission to younger generations.

This author distinguishes three types of factors for achieving obedience in an organization: the use of force (coercion), the economic factor (remuneration), and moral adherence (to the purposes of the organization). They are ideal types that are not expected to be found in isolation in any real case. With respect to Brazilian basic schools, especially public ones, it is clear that the obedience of the people involved in this kind of organization derives fundamentally from the degree of adherence to its goals.

According to this approach, the main source of control of participants at the lower levels of the organization - for example, teachers - is the normative power and secondarily the remunerative power, because wages are widely recognized as degrading, and bonuses and the manipulation of payments fail to induce the internalization of values; they ultimately produce only superficial engagement. In these organizations, consent (participation) is 
mainly based on the internalization of normative guidelines accepted as legitimate, and is designated as a moral participation; for this to occur, participants need to be in agreement with the ideas with which the organization operates. Our research was able to verify that some particular government programs were more easily accepted than others within the same school - that is, in the same context of teacher involvement with the reforms, with the same degree of imposition, and under the same material conditions. This led us to infer that the teachers' ideas variable can be reaffirmed as an explanation for the different levels of adherence. These results reinforced the thesis of Etzioni's theory of organizations on the importance of the symbiosis between the teachers' ideas and those underlying the reforms, in order for teachers to engage in those.

The concept of educational reform used here is based on Ghanem (2006), and Torres (2000), who consider the reform as a logic that comprises planning in a context that is external to the execution, along with broad scope, financial support, homogeneity, and an imposing character.

We use a broad concept of reforms. These encompass programs that are modalities of action and may have definite deadlines or not; such programs stem from a number of policy lines, such as those aimed at administrative modernization, the qualification of personnel, compensation, or certain inputs, as in the case of textbooks.

There has been concern with resistance to reforms, teacher education and professionalization for decades and it is still very marked. These issues are at the heart of the debate on the quality of education. Researchers, educators, reformers, international organizations, and organized civil society attribute what they call poor education to poor teacher education. In this way, they strive to reveal how good teacher education occurs and what knowledge is necessary to establish good teaching; however, they pay little attention to teachers' ideas about education, which are the result of the socialization to which teachers were subjected.

\section{Approaches to Teacher Resistance}

The following discussion is not intended to judge the merits or the need for educational reforms. Its intention is to examine studies of varied, even opposing inspirations and perspectives that bring substantive information about teacher resistance to educational reforms.

In this literature, many authors claim that teachers are the impediments to reform, and attribute such fact to their unsatisfactory training. Torres $(1996,2000)$, for example, indicates the existence of a historical conflict between this professional category and educational reformers worldwide, in particular in Latin America. The author describes aspects of the teaching work that critics classify as those that would explain their poor training, such as: outdated content and educational methods; theoretical work unrelated to practice; encyclopedic teaching, lagging in relation to new technologies etc. These criticisms have supposedly led reforming groups to introduce improvements in-service teacher education, not in initial teacher education, which does not solve the issue. 
Gusmão (2010) addressed members of entities related to education in Brazil - Instituto Ayrton Senna (Ayrton Senna Institute), União dos Dirigentes Municipais de Educação (Undime - Union of Municipal Education Managers), Confederação Nacional dos Trabalhadores em Educação (CNTE - National Conference of Education Workers), and Campanha Nacional pelo Direito à Educação (National Campaign for the Right to Education) - and noted that those who lead the entities - which represent very different social groups, and have markedly disparate political orientations - also conceive teachers as a key piece or obstacle to educational transformation. Regarding teachers' appropriation of and resistance to educational policies, Santos (2011) shows teachers as obstacles to the implementation of reforms. The author argues that reforms are not implemented by teachers in the way that reformist centers want them to be, because teachers do not feel part of the reform and therefore act according to the needs of their immediate doing, of the reality of the classroom, depending on the structural conditions encountered, since they ignore the basis of the proposals and discredit them. Although these proposals provoke discomfort in the school, they are treated differently from what was thought out and proposed by official agencies.

On educational reforms in the 1990s, specifically in Latin America, Oliveira (2006) states not only that reformers see teachers as primarily responsible for the performance of students, the school and the system, but also that teachers are also obliged, due to the reforms, to respond to demands that are beyond their training. Gajardo (1999), on the other hand, when referring to the general characteristics of these reforms, also mentions teachers as obstacles and indicates the lack of human competencies as one of the factors responsible for the poor results of reforms, besides the inability of the institutions and the lack of efficient information and communication networks that facilitate interaction between actors and that involve the whole society in the reform.

Rego and Mello (2004), analyzing various studies in Latin America and the Caribbean, state that they attribute the success or failure of the reforms to the level of persuasion and transformation of teachers. As a consequence, they emphasize teacher education and list what they consider relevant lessons concerning the factors responsible for the good quality of education, namely: the level of education in which the training takes place; connection between theory and practice; the appreciation of practice; the organic institutional link between training and the reality of primary and secondary schools; the link between initial and in-service teacher education; the fact that the concept of quality in primary and secondary schools is outdated in relation to contemporary demands; and consequently the desired teacher profile. Some aspects linked to these points are then added, one of which is the fact that teacher education is disconnected from what will be demanded from them in compulsory education. The same authors also point out the need for in-service education courses to depart both from what teachers have learned - and how they have learned - and from the contents that need to be resignified in order to acquire meaning in academic and professional life.

Reinforcing the idea of poor teacher education and the need to improve it, Vaillant (2004) - in a publication by Programa de Promoción de La Reforma Educativa en América 
Latina y el Caribe (Preal - Program for the Promotion of Educational Reform in Latin America and the Caribbean) ${ }^{3}$ - analyzes the construction of the teaching profession in Latin America; the author asserts that one of the main challenges currently faced by education policies is the improvement of teacher performance. In relation to the teachers of developed countries, Latin American teachers are thought to be less prepared, to have fewer years of schooling, to come from a family with low cultural and economic capital, to be recruited more and more in sectors of lower educational and cultural levels. In other words, teacher education in Latin America is one of the major obstacles to the development of education, since teachers come from compulsory education based on oral presentations and poorly prepared teachers (VAILLANT, 2004).

Navarro, Carnoy and Castro (2000) also consider that initial teacher education is poor and needs to be improved because it is one of the crucial points for the success of the reforms. The authors also point out that in-service education has not been able to include all the teachers, or yield results.

To broaden the view on teacher resistance in the Americas, it is imperative to highlight Ravitch (2011), ${ }^{4}$ who analyzed some educational reforms within the US, especially the federal reform expressed in the slogan No Child Left Behind (NCLB), which occurred in the last decade of the twentieth century and at the beginning of this century. Ravitch (2011) concludes that two decades of reforms have not improved education and that all we have seen are teachers and management creating strategies for students to perform well in the tests, and therefore the curricula of the schools using such performance as a reference. She evaluates that one of NCLB's mistakes was to consider those who worked in schools incapable: "Good education cannot be achieved by a strategy of testing children, shaming educators, and closing schools" (RAVITCH, 2011, p. 132). In these analyzes, teachers are considered an important piece for the reform, an obstacle to its realization, although they played the game of the reformers, contributing to positive statistical results. There is veiled confrontation with reform, because contestation would be punished.

Regarding the reform of the Portuguese educational system, ${ }^{5}$ Vilar (1993), who addressed the importance of innovation and research in education, also attributed its success to teachers' commitment to the reform. Vilar indicated the training and improvement

3 Preal aims to contribute to the improvement and equality of education through educational debates and reforms. Created in 1996 and based in Chile, it is co-directed by the Inter-American Dialogue, funded by the United States Agency for Economic Development (USAID) and by IDB. Cf. WERLANG, A. C.; VIRIATO, E. O. O Programa para Reforma Educacional na América Latina e Caribe (PREAL) e a política e formação docente no Brasil na década de 1990. Form. Doc., Belo Horizonte, v. 4, n. 6, p. 10-23, jan./jul., 2012). Available: $<$ http://formacaodocente.autenticaeditora.com.br $>$. Access: 11 feb. 2013.

4 Researcher at New York University; in 1991, she assumed the position of assistant secretary of the National Secretary of Education of George W. Bush government and was an advisor for Bill Clinton and George W. Bush governments.

5 The author refers to the first phase of the Portuguese Educational Reform (1986-1995). To learn more about the Portuguese Education Reform, please see: LIMA, C. L. Administração escolar em Portugal: da revolução, da reforma e das decisões políticas pós-reformistas. In: CATANI, A. M.; OLIVEIRA, R. P. (Orgs.). Reformas educacionais em Portugal e no Brasil. Belo Horizonte: Autêntica, 2000, p. 41-76. 
of teachers was one of the strategies of implementation of the reform. Webb et al. (2004), in turn, in a comparative study between professionalism of primary teachers in the United Kingdom and Finland, found in both countries the teacher resistance to abandoning old practices and accepting the State-led reform.

The report to the United Nations Educational, Scientific and Cultural Organization (Unesco) of the International Commission on Education for the 21st Century, "Education: a treasure to discover", which provided the basis for Unesco to guide various educational refor$\mathrm{ms}$, makes the new teaching assignments explicit, which are completely beyond the ordinary ones. The Commission also makes clear that teachers are not prepared for new assignments and indicates the need to improve recruitment and "[...] to rethink teacher education in order to cultivate in future teachers precisely the human and intellectual qualities capable of fostering a new teaching perspective in the sense proposed by this report" (p. 157).

In general, the picture is one of agreement on the issue of teacher resistance linked to poor training. Therefore, some studies point to the need to reformulate bachelor of education degree programs (cursos de licenciatura) and promote in-service training.

\section{Teacher Education and Teachers' Ideas}

Among research on educational innovation, Huberman (1976) and Neirotti and Poggi (2005) draw attention to the complexity of resistance to reforms in schools and highlight the importance of teachers' values and practices. From this observation, we come to conceive values and practices as linked to the ideas teachers have about education.

According to "Dicionário Houaiss da Língua Portuguesa" (2001), among the various meanings, the term idea corresponds to knowledge, information, notion of what it is; way of seeing, opinion thought or formulated; intention to accomplish (something), plan, purpose, design; mind, thought; set of opinions of an individual or a group of people on some issue. Therefore, the term idea encompasses thought, beliefs, knowledge, representations, and skills.

There is an epistemological discussion about teachers' ideas within which the concepts of skills, knowledge, thoughts, representations, and beliefs of teachers are present; these concepts sometimes appear tangled, other times as synonyms, and sometimes separated. Tardif (2002) created a model of analysis of the teaching work that encompasses beliefs and knowledge of teachers within the concept of teacher knowledge.

In 1991, Tardif proposed a model of analysis of the diversity of teacher knowledge, which differs from the typologies proposed by Gauthier, Schulman and García, authors who stood out in this field. Tardif (2002) conceptualizes teacher knowledge as knowledge, competencies, skills, and attitudes of teachers, involving beliefs. He conceives it as plural, temporal, rational, and heterogeneous knowledge. Such knowledge consists of several other types of knowledge (professional, curricular, disciplinary, and experiential), coming from different sources (compulsory education institution, family, professional qualification, curricula, and everyday practice) throughout the life trajectory of the teacher. Profes- 
sional knowledge is that transmitted by the institutions that train teachers, it is pedagogical knowledge (conceptions or doctrines, such as pedagogical doctrines centered on the ideology of the New School), and the knowledge of education sciences (Psychology of Learning and Development), which are linked. Curricular knowledge is the knowledge about school programs (content, methods, objectives), social knowledge selected by the school as a model of culture and erudite education, which must be worked on by the teacher. Disciplinary knowledge is that of a specific field of knowledge (Mathematics, Chemistry, Physics, and others), acquired in university education programs. Experiential knowledge is developed in everyday school practice, "it is the teaching culture in action". The construction of this knowledge takes place in the school environment, in which teachers interact with the other actors of the school (such as older peers, who convey collective experiential knowledge), submit their work to the various obligations and norms of the school (for example, school programs) and to the hierarchical organization of functions that comprise it, that is, experiential knowledge is constructed under "certain conditions of the profession". Under these conditions, the teacher tests, filters, adapts, retranslates the knowledge learned in the initial training; everyday work requires improvisation and personal skills and, with this, the teacher develops a style of teaching, a know how to do, a know how to be, and the process of building this experiential knowledge becomes a training process as well:

[...] Experiential knowledge emerges as the vital core of teacher knowledge [...]. In this sense, the experiential knowledge is not knowledge like the other; it is, on the contrary, formed of all the other types of knowledge, but retranslated, "polished" and subjected to the certainties built in practice and experience [...] (TARDIF, 2002, p. 54).

Because teacher knowledge is temporal, in the initial teacher education and the beginning of the careers of future teachers, they act according to the beliefs, values and norms of teaching internalized before they pursued professional qualification. Throughout the career, which is formative, these beliefs can be reinforced or not, according to Tardif.

Torres (1996) confirms the weight of school socialization in teacher training when she mentions the importance of observing the (authoritarian, encyclopedic, passive, repressive) school system in which the teacher was educated, because, according to her, daily contact with such a school model leads to the internalization of values, methods and practices that will constitute the future teacher's practice:

The school experience seems to be stronger than what was learned in teacher education. Going back and unlearning what one has learned is difficult and often unsuccessful, when one has lived for many years in an authoritarian, rigid, disciplinary, passive educational model as the only reference and even as a socially recognized school exponent of "good education" (TORRES, 1996, p. 43).

Lahire (2004), in turn, reinforces the above, since for this author dispositions are incorporated in different ways, as well as their updating, which may or may not occur; 
and the more precocious, regular and intense the internalization, the greater the chance of the disposition being strong, as a "second nature". That is, the intensity of dispositions (habits) is related to the moment of life in which they were internalized and to the context of updating (LAHIRE, 2008). Therefore, dispositions (mental and action habits) that were internalized in basic education and reinforced in teaching practice due to coexistence with peers and with the school structure (which has had little change) point to the fact that the teachers' ideas are linked to a particular conception of school, and that they will be refractory to reforms that contradict this conception.

\section{Teachers Disagree with Governmental Programs}

The more one examines the studies available, the more clear the relationship between teachers' ideas and resistance to educational reforms becomes, as if they worked with different logics. Carraro (2002), for example, interviewed forty teachers from two schools of the educational system of the interior of São Paulo state, aiming to investigate the beliefs and representations of primary education teachers about constructivism, Parâmetros Curriculares Nacionais (PCN - National Curricular Parameters), and pedagogical innovations. This author calls pedagogical innovations deriving from Lei de Diretrizes e Bases da Educação (LDB - Law of Guidelines and Bases of Education) of 1996 the following: continuous progression, school cycles, and computer science as a didactic resource. Based on the literature on the subject, the author assumes that the PCNs have constructivist theoretical foundations and thus propose new didactic and methodological techniques. According to the author, just as the LDB 1996, the PCNs brought educational innovations which led to the implementation of school cycles, continuous progression, and a process of evaluation and methodological practice related to constructivist orientations.

However, the author notes that, although teachers felt pressured to work according to the constructivist ideology, following the PCNs, they revealed that they had inaccurate or misleading notions about the PCNs, as well as about continuous progression and school cycles, and were also insecure to use computers as a teaching resource. The survey also revealed that, while recognizing the need for reform, teachers did not agree with reforms because they did not know them or did not agree with their principles, or because such reforms had been imposed on them.

Carraro (2002) highlights, among others, the need for greater investment in and commitment to initial and continuing teacher education. The author evidences, in this way, that there is a problem with teacher education, which hinders the implementation of reforms. It is important to stress that, among the aforementioned factors of non-adherence to reforms, there is teacher disagreement about the principles of reforms.

Addressing the impact that Programa de Avaliação da Alfabetização do Estado de Minas Gerais (Proalfa - Literacy Assessment Program of Minas Gerais State) ${ }^{6}$ may have on

6 Proalfa is a census evaluation of Minas Gerais state for students of the 3rd grade (aged 8 years) and a sample evaluation for those of the 2nd and 4th grades; it aims to assess the level of student proficiency. 
teaching practice, Carvalho and Macedo (2011) point out that the occasional resistance to the program stems from its imposition, which generates a lack of further information and a sense of non-belonging. The authors say that teachers recognize the value of the material sent by the State Department of Education, although it is produced by academics, but teachers do not use it in everyday practice or appropriate it; in fact, they create strategies to circumvent the guidelines with which they do not agree and act the way they believe to be right.

As for the implementation of learning cycles, Mainardes $(2007 ; 2009)$ examines Brazil as a whole and Araújo (2006) only Mato Grosso do Sul state, but the three studies point to teacher resistance as one of the obstacles to organizing schools in cycles. They attribute the resistance to the fact that teachers' educational experiences are linked to the traditional school model (student assessment ranking, failure, graded organization, selection, and others), and to the lack of school infrastructure to implement learning cycles. Mainardes $(2007 ; 2009)$ also adds as resistance factors the imposing character, the complex nature of cycles, the strategies used for their implementation, and the Brazilian school culture.

Also on the issue of learning cycles, Cunha (2007) reveals that most of the authors that he consulted indicated teacher resistance to the policies of implementation of cycles in school systems. According to these authors, the causes of resistance vary: some attribute it to lack of knowledge of the characteristics and scope of the proposal; others attribute it to lack of infrastructure and staff training; others to the fact that it was the result of an authoritarian policy, without the participation of teachers; others to teachers' inability to extricate themselves from the graded school culture, from the conception of education already internalized. In some cases, the authors indicate more than one cause. In a study in a school of São Paulo City education system, Cunha (2007) also found teacher resistance to cycles and to continuous progression for reasons similar to those listed above: authoritarian implementation of cycles and not consulting teachers, which made it difficult for them to appropriate the proposal; superficial understanding of the issue; and discontent for conceiving the cycle only as a policy which aims to improve failure and dropout rates.

Jacomini (2004), based on the assumptions that the effectiveness of public policies depends mainly on teachers and that they resist the implementation of cycles and continuous progression, analyzed teacher actions in four episodes of the implementation of cycles in the public education systems of São Paulo City and State: i) the 1967-1968 Reform (state education system); ii) the implementation of the Basic Literacy Cycle in 1983-1984 (state education system); iii) the adoption of cycles and continuous progression in 1992 (São Paulo City education system); and iv) the introduction of the continuous progression scheme in 1998 (state education system). The study sought to uncover the causes of resistance; three types of teacher resistance determinants ${ }^{7}$ to learning cycles and continuous progression were analyzed, namely: i) materials (provision of adequate and sufficient physical space, necessary pedagogical materials etc.); ii) ideological determinants (beliefs that are built

7 According to Jacomini (2004), the concept of determinant (condicionante in Portuguese) was based on PARO, V. H. Por dentro da escola pública. São Paulo: Xamã, 1996, 400 p. 
historically and that determine the way of thinking and acting of each one); and iii) institutional pedagogical determinants (functional and organizational conditions of the school).

The researcher verified that, to some extent, the determinants are repeated in the episodes analyzed, that is: the faculty claimed to be supportive of cycles and continuous progression since they provided the democratization of teaching and overcame school failure; however, the faculty argues that, since there are no material, institutional or pedagogical conditions for their operation, they should not be adopted, as they further compromise the quality of teaching. However, for that researcher, the great factor in teacher resistance is teachers' ideas about education.

Reviewing the studies produced on policies on learning cycles in Brazil from 1990 to 2005, Barreto and Souza (2005) state that teachers do not adhere to cycles because they understand that, with cycles, they lose the mechanism of control and power over students - failure - and also control over the process of teaching and learning. The authors see in this fact evidence that the information disclosed to teachers has not been able to break with teachers' conceptions of evaluation practices. They also point out the need to work more on school culture and values in order to make inclusive education feasible.

Regarding the continuous progression scheme, when observing teacher resistance in a state school in Campinas, Jeffrey (2006) attributed it to teachers' lack of knowledge about the guiding conceptions and foundations of this scheme, and stated that teachers guide their practice through the foundations and conceptions they already knew, with which they feel safe, that is, those related to graded school. The researcher highlights teachers' concern to create their own dynamics to preserve their convictions and their educational parameters. Another case is that of teachers who neglect the Common Core Curriculum created by Projeto de Reforma Curricular da Educação Básica do Estado de Minas Gerais (Curricular Reform Project for Minas Gerais State Compulsory Education). Greco (2012) emphasizes that teachers failed to have broad understanding of the reform, and therefore of the curricular changes that it demanded. This group of professionals uses as reference above all the textbook, the entrance exam of public universities, and the evaluations applied to schools by the federal and Minas Gerais state governments.

Also on curricular reforms, Cruz (2007) points out the importance of the teacher for their implementation and, after presenting some authors who share the same reflection (such as Giroux $^{8}$ and Moreira ${ }^{9}$ ), Cruz concludes that, when there is a gap between the conception of curricular reform and the teacher, it is bound to fail. The same happens with the school's difficulty to develop collective work and consequently to implement the school's pedagogical project according to article 12 (item I) of Law 9,394/96, of Guidelines and Bases of Education. Azanha (2000, 1998) attributed this difficulty mainly to the teaching tradition reiterated in teacher education and argues that, although the expansion of primary

8 GIROUX, H. Professores como intelectuais transformadores. In: Os professores como intelectuais: rumo a uma pedagogia crítica da aprendizagem. Porto Alegre: Artes Médicas, 1997, p. 157-164.

9 MOREIRA, A. F. B. A crise da teoria curricular crítica. In: COSTA, M. V. (Org.). O currículo nos limiares do contemporâneo. Rio de Janeiro: DP\&A, 1998, p. 11-36. 
education in Brazil has given rise to an institution that demands collective work, which breaks with the school "inspired by a preceptorial view of the pedagogical relation" (p. 11), teacher education continues to be based on methods and procedures of someone who teaches and of the skills, competencies, and psychological qualities of someone who learns. A tradition of ideas that have underpinned the bachelor of education degree programs since their creation in Brazil. The idea that a "good teacher" is someone who can teach well his or her subject of choice has persisted. Therefore, according to the author, the teacher who internalized the idea of individual teaching work finds it difficult to understand the educational task as collective, which exceeds the limits of the teaching and learning of disciplines.

It is worth mentioning Franco (2008), who researched the logics ${ }^{10}$ that govern the teaching practice and verified that the logic of the latter is different from that of professional education, because it is based on experiences prior to training and is organized around distinct epistemologies. By the logic of practice, teachers do not consider the scientific knowledge apprehended in their professional education sufficient for everyday school reality, and resort to cultural mechanisms apprehended in their own broad process of socialization. In addition, Franco points out that teachers do not always put into practice what they think and say, since they act mechanically, not reflexively and, in this way, defend themselves from the destabilization that something new may cause. According to the author, this is a kind of survival mechanism against reform.

\section{The Compulsory Education of Those who Became Teachers}

Assuming that compulsory education has great influence on the training of the future teacher makes it important to consider some characteristics of the history of the Brazilian educational system. Rego (2012) focused on the role played by schooling in the psychological constitution of people who attended public compulsory school forty years ago. She identified the predominant pedagogical model at the time by means of the description that those people made of it. Such model was centered on: the figure of the teacher; repression; overvaluing the transmission and memorization of knowledge to the detriment of the affective, corporal and social dimensions; rigid behavioral control; punishments; abstract knowledge; the disregard of the cultural universe from which the student came. The author also found that this model of school, this school culture experienced by the students, has impacts and consequences on their psychosocial constitution, although other factors - students' social and cultural context - also contribute to such constitution. These data reinforce the argument that, having been educated in a given school model, future teachers tend to internalize pedagogical values and practices conveyed by this model, and to constitute an educational ideology from there.

10 Franco (2008) works with the concept of logic in the sense of paths "built" by thought to explain and understand reality according to how it presents itself with meaning to the subject. This conception is based on CHARLOT, B. Enseigner, former: logique des discours constitués et logique des pratiques. Recherche et formation. Paris, v. 8, out. 1990. 
Frigotto (2011) is one among others that interprets our colonial slavery past as a relevant factor in the delay of the constitution of the capitalist spirit and in the inability of the ruling class to complete the bourgeois revolution, facts that have influenced the quality of education. He cites Oliveira, for whom:

[...] the class relations that were built in Brazil allowed only partially and precariously the existence of the Fordist mode of regulation both technologically and socially. In the present, the same occurs in the current scientific-technical change of digital-molecular nature, which causes a great obsolescence of knowledge. [...] A society therefore in which, in the international division of labor, activities linked to simple work and to a few niches of complex work prevail (OLIVEIRA, 2003, p. 87-88).

This approach reinforces the thesis of Moreira (1990), Romanelli (1978) and Moreira (1959) on the predominance of classical school, with a scientific and cultural basis, in relation to the technical school, in line with the Brazilian economic and political model. According to Romanelli and Moreira, the labor market trained its staff without the real need to attend technical school; therefore, attending classical school and obtaining academic degrees would yield high status (it would free the individual from unpopular and unloved physical work in a society with a long slavery past), enabling entry into higher education and social ascension.

This trend is evident in the analysis of the history of Brazilian education by Souza (2008), who explains the government's difficulty in changing the classical humanist curriculum for the scientific and technical one in the 1960s and 1970s, although the legislation so determined. The Law of Guidelines and Bases of National Education, Law No. 5,692, of 1971, which aimed to modernize the curriculum, adapting it to the economic and political moment of the time, also faced difficulties to be complied with, especially in relation to the professionalization of secondary education, having received several criticisms from various sectors of society, including students, intellectuals, teachers, and private school owners. In the face of objections and difficulties, in 1982 the mandatory professionalization of this level of education was definitely revoked.

Souza (2008) is attentive to the fact that, in that period, the reformers sought to give a new connotation to the concept of humanism, relating it to scientific knowledge, which, according to them, is indispensable for the constitution of the individual, as a justification for changing the curriculum; this element seems to highlight the function of the school until then as a civilizer, as a trainer of individuals with specific knowledge and behaviors with which they would become deserving of social status, recognition and distinction. This picture seems to have changed in the $1990 \mathrm{~s}$, a period when access to primary education gradually became universal and secondary education greatly expanded. The legislation deriving from the new Law of Guidelines and Bases of National Education (1996), which consolidated the curriculum based on elements of the scientific culture, brought to light some old proposals that have not been consolidated, most of the time because they were not accepted by society, such as cycles and diagnostic evaluation. 
At the global level, in 1989 in Paris, the Center for Education Research and Innovation (Ceri) held a conference in which researchers from the field of education and psychologists gathered to initiate studies and discussions on curricular reform in the member countries of the Organization for Economic Co-operation and Development (OECD). Such reforms aimed to change the fact that the compulsory education of these countries was limited to providing knowledge that traditionally makes up school curricula, providing them with the opportunity to also develop the complex intellectual abilities required by the labor market and needed for the exercise of citizenship in democratic societies. This concern was motivated by the understanding that the quality of education is essential to meet the growing and complex social and economic needs (AZANHA, 2006).

In the 1990s, the Brazilian Ministry of Education introduced education based on the development of competencies; this concept began to guide the structuring of teaching and to define "the contents" to be taught, as well as how the faculty should teach and evaluate. Official documents define competencies as structural modalities of intelligence, from which skills in the field of action derive. Such complex changes within the educational system demanded a new teacher education, which did not materialize, but the reformer assumed that teaching practices would be transformed simply by the acquisition of new concepts and teachers' accountability for their professionalization and for the results of their performance (ALMEIDA, 2009). What was forgotten, says Carvalho (2011), is that teaching practices derive from ethical and political principles, from the culture of school institutions, from the peculiarities of each social group in which they are located, which have been historically consolidated. Thus, the didactic-methodological propositions derived from theoretical perspectives which ignore these principles have not and will not succeed, since:

[...] The idea of competence, which is a core idea in the proposition of the reform, continues to be subject to a different understanding or even ignored by the faculty and managers of education systems, who continue to carry out educational actions based on their knowledge and pedagogical beliefs (ALMEIDA, 2009, p. 89; emphasis of author).

\section{Conclusion}

This set of systematic research results allows highlighting the importance of teachers' ideas for the success of educational reforms, provided that it is admitted, according to the structuralist approach of organizations, that, for the school to achieve its objectives, the faculty needs to be engaged and such engagement depends on their agreeing with the ideas from which the guidelines - established for the organization in which the faculty operates - derive.

Accordingly, in specialized literature, it was also possible to verify that teachers' educational ideas, albeit not the only one, are a major factor in teacher resistance to educational reforms. Government programs based on ideas linked to those with which teachers were socialized are more easily accepted than ideas based on other pillars. 
On the other hand, assuming the theory of Tardif (2002), teachers' educational ideas derive above all from their socialization in compulsory education, which is sometimes reinforced in professional education and professional experience.

Therefore, the accumulated knowledge about the subject leads us to infer that, instead of assuming that resistance to educational reforms is due to poor teacher training, it is more appropriate to understand it, among other factors (misinformation about the reform progra$\mathrm{ms}$, the taxing nature of their implementation etc.), as a discrepancy between teachers' ideas and many of the ideas that guide educational reforms, the former resulting from teachers' socialization processes, especially as compulsory education students.

\section{REFERENCES}

ABBAGNANO, Nicola. (2007). Dicionário de filosofia: edição revista e ampliada, 5. ed. Tradução de Alfredo Bosi e Ivone Castilho Benedetti. São Paulo: Martins Fontes.

ALMEIDA, M. (2009). Professores e competências - revelando a qualidade do trabalho docente. In: ARANTES, V. A. (Org.). Educação e competências: pontos e contrapontos (p. 77-122). São Paulo: Summus.

ARAÚJO, M. I. B. (2006). Resistência docente à escola ciclada. Brasília: Líber Livro.

AZANHA, J. M. P. (2006). É possível ensinar a pensar? In: Formação do professor e outros escritos (p. 25-36). São Paulo: Senac.

AZANHA, J. M. P. (1998). Proposta pedagógica e autonomia da escola. Cadernos de História e Filosofia da Educação, II, (4), p. 11-21.

AZANHA, J. M. P. (2000). Uma reflexão sobre a formação do professor da escola básica. Relatório ao Conselho Estadual de Educação. Processo n. CCE 64/69, 4-21.

BARRETO, E. S. S. \& Sousa, S. Z. (2005). Reflexões sobre as políticas de ciclos no Brasil. Cadernos de Pesquisa, 35, (126), 659-685.

CARRARO, P. R. (2002). Crenças e representações dos professores sobre o construtivismo, os parâmetros curriculares nacionais (PCN) e as inovações pedagógicas, no contexto das diretrizes propostas para o ensino fundamental a partir da nova LDB. Dissertação (Mestrado em Educação). Programa de Pós-Graduação em Educação. Universidade de São Paulo. Ribeirão Preto: USP.

CARVALHO, G. F. S. \& Macedo, M. A. N. (2011). Avaliação oficial: o que dizem os professores sobre o impacto na prática docente. Educ. Pesquisa, São Paulo, 37(3), 549-564.

CARVALHO, J. S. F. (2011). A teoria na prática é outra?: considerações sobre as relações entre teoria e prática em discursos educacionais. Revista Brasileira de Educação, Rio de Janeiro, 16 (47), 307-322. 
CRUZ, B. (2007). A prática docente no contexto da sala de aula frente às reformas curriculares. Educar. Curitiba: Editora UFPR, n. 29, 191-205.

CUNHA, I. B. (2007). A postura docente diante dos ciclos de aprendizagem. Dissertação (Mestrado em Educação) - Programa de Pós-Graduação em Educação. Universidade de São Paulo, São Paulo: USP.

DELORS, J. (1998). Educação: um tesouro a descobrir: relatório para a Unesco da Comissão Internacional sobre Educação para o século XXI. São Paulo: Cortez; Brasília, DF: MEC: Unesco.

ETZIONI, A. (1974). Análise comparativa de organizações complexas: sobre o poder, o engajamento e seus correlatos. Tradução de José Antônio Parente Cavalcante e Caetana Myriam Parente Cavalcante. Rio de Janeiro: Zahar; São Paulo: Universidade de São Paulo.

FRANCO, Maria Amélia Santoro (2008). Entre a lógica da formação e a lógica das práticas: a mediação dos saberes pedagógicos. Educ. Pesquisa, 34 (1), 109-126. http://dx.doi. org/ 10.1590/S1517-97022008000100008.

FRIGOTTO, G. (2011). A qualidade da educação escolar no Brasil: um contraponto à concepção hegemônica. In: BERTUSSI, G. T. \& OURIQUES, N. (Coords.). Anuário educativo brasileiro: visão retrospectiva (p. 79-103). São Paulo: Cortez.

GAJARDO, M. (2000, setembro). Reformas educativas na América Latina: balanço de uma década. Tradução de Paulo M. Garchet. PREAL Documentos. Retirado de www. cpdoc.fgv.br/comum $/ \mathrm{htm} /$.

GHANEM, E. (2006). Mudança educacional: inovação e reforma: relatório científico 2: final. São Paulo.

GHANEM JÚNIOR, E. G. G. (2013). Reforma educacional no estado de São Paulo dos anos 1990 (Trabalho apresentado na 32 ${ }^{\text {a }}$. Reunião Anual da Anped, 2009). Retirado de http://www.anped.org.br/reunioes/32ra/arquivos/trabalhos/GT14-5910--Int.pdf.

GRECO, F. A. S. (2012). Com que referências trabalham os professores no currículo do ensino médio? Um estudo sobre o ensino de geografia nas Escolas - Referência de Uberlândia/MG. Tese (Doutorado em Educação). Programa de Pós-Graduação em Educação. Universidade de São Paulo. São Paulo: USP.

GUSMÃO, J. B. B. (2010). Qualidade de educação no Brasil: consenso e diversidade de significados. Dissertação (Mestrado em Educação). Programa de Pós-Graduação em Educação. Universidade de São Paulo. São Paulo: USP.

HOUAISS, A. \& VILLAR, M. S. (2001). Dicionário da língua portuguesa. Rio de Janeiro: Objetiva.

HUBERMAN, A. M. (1976). Como se realizam as mudanças em educação: subsídios para o estudo do problema da inovação. Tradução de Jamir Martins. São Paulo: Cultrix. 
JACOMINI, M. A. (2004). A escola e os educadores em tempo de ciclos e progressão continuada: uma análise das experiências. Educ. Pesquisa, São Paulo, 30 (3), 401-418.

JEFFREY, D. C. (2006). Representações de docentes sobre o regime de progressão continuada: dilemas e possibilidades. Tese (Doutorado em Educação). Programa de PósGraduação em Educação. Universidade de São Paulo. São Paulo: USP.

LAHIRE, B. (2004). Retratos sociológicos: disposição e variação individuais. Tradução de Didier Martin e Patricia Chittoni Ramos Reuillard. Porto Alegre, RS: Artmed.

. (2008). Esboço do programa científico de uma sociologia psicológica. Tradução de Felipe de Souza Tarábola. Educação e Pesquisa, São Paulo, v. 34, n. 2, mai./ago. p. 373-389.

MAINARDES, J. (2007). Reinterpretando os ciclos de aprendizagem. São Paulo: Cortez.

MAINARDES, J. (2009). A pesquisa sobre a organização da escolaridade em ciclos no Brasil: (2000-2006): mapeamento e problematizações. Revista Brasileira de Educação, Rio de Janeiro, 14, (40), 7-23.

MOREIRA, A. F. B. (1990). Currículos e programas no Brasil. Campinas, SP: Papirus. MOREIRA, J. R. (1959). Hipóteses e diretrizes para o estudo das resistências à mudança social, tendo em vista a educação e a instrução pública como condições ou fatores. Curitiba: Associação de Estudos Pedagógicos.

NAVARRO, J. C., CARNOY, M.\& CASTRO, C. M. (2000). La reforma educativa en América Latina: temas componentes e instrumentos. In: NAVARRO, J. C. et al. (Ed.). Perspectivas sobre la reforma educativa: América Central en el contexto de políticas de educación en las Américas (p. 1-45). Argentina: La Agencia de Estados Unidos para El Desarrollo Internacional, Banco Interamericano de Desarrollo, Instituto de Harvard para el Desarrollo Internacional.

NEIROTTI, N. \& POGGI, M. (2005). Alianças e inovações em projetos de desenvolvimento educacional/local. Brasília: Unesco; Buenos Aires: IIPE.

OLIVEIRA, D. A. (2006). Regulação educativa na América Latina: repercussões sobre a identidade dos trabalhadores docentes. Educação em Revista, Belo Horizonte, 44, 209-227.

OLIVEIRA, F. (2003). Crítica à razão dualista. São Paulo: Boitempo.

RAVITCH, D. (2011). Vida e morte do grande sistema escolar americano: como os testes padronizados e o modelo de mercado ameaçam a educação. Porto Alegre: Sulinas.

REGO, T. C. (2012). Narrativas autobiográficas, singularidades e suas interfaces com a educação: contribuições da perspectiva histórico-cultural. Tese (Livre Docência). Programa de Pós-Graduação em Educação. Universidade de São Paulo, São Paulo: USP. 
REGO. T. C. \& MELLO, G. N. (2004). Formação de professores na América Latina e Caribe: a busca por inovação e eficiência. In: PEARLMAN, M. et al. Maestros en América Latina: nuevas perspectivas sobre su formación y desempeño (p. 165-212). Santiago: PREAL/BID.

ROMANELLI, O. O. (1978). História da educação no Brasil (1930/1973). Petrópolis: Vozes.

SANTOS, J. M. C. T. (2011). Apropriação e resistência: ressignificação das políticas educacionais na prática docente. Acta Scientiarum. Education, Maringá, 33 (1), 149-155.

SOUZA, R. F. (2008). História da organização do trabalho escolar e do currículo no século XX: ensino primário e secundário no Brasil. São Paulo: Cortez.

TARDIF, M. (2002). Saberes docentes e formação profissional. Tradução de Francisco Pereira. Petrópolis, RJ: Vozes.

TORRES, R. M. (2000). Reformadores y docentes: el cambio educativo atrapado entre dos lógicas. In: Foro Los docentes, protagonistas del cambio educativo (p. 1-89). Bogotá.

TORRES, R. M. (1996). Formación docente: clave de la reforma educativa. In: Nuevas formas de aprender y enseñar. Santiago: Unesco-Orealc.

VAILLANT, D. (2013, dezembro). Construcción de la profesión docente en América Latina: tendencias, temas y debates. Retirado de www.preal.org.

VILAR, A. M. (1993). Inovação e mudança na reforma educativa. Rio Tinto, Portugal: Asa.

WEBB, R. et al. (2007). A comparative analysis of primary teacher professionalism in England and Finland. Comparative Education, 40 (1), 83-107. http://dx.doi. org/10.1080/0305006042000184890

Elie Ghanem has a degree in pedagogy (1986), a master's degree (1992) and a doctorate (2000) in Education at the University of São Paulo, where he works. He is mainly interested in educational change, quality of education, school management and democracy. He is responsible for the research group Ceunir-University Center for Research in Innovation, Reform and Educational Change.

Maria Socorro Torquato holds a degree in Social Sciences and Politics from the School of Sociology and Politics of São Paulo, a degree in History from the Thereza Martin Foundation, a Master's Degree in Sociology from the University of São Paulo (2002) and a PhD in Education by the same university (2015). She has been a teacher in higher education since 2002, working in undergraduate and graduate courses. She is currently a professor at the Federal University of São Carlos. She has experience in the area of sociology of education, curriculum, public policies and educational reform.

Submitted: 19/09/2017

Approved: 28/05/2018 